\title{
Illiteracy, low educational status, and cardiovascular mortality in India
}

\author{
Mangesh S Pednekar ${ }^{1 *}$, Rajeev Gupta ${ }^{2}$ and Prakash C Gupta ${ }^{1}$
}

\begin{abstract}
Background: Influence of education, a marker of SES, on cardiovascular disease (CVD) mortality has not been evaluated in low-income countries. To determine influence of education on CVD mortality a cohort study was performed in India.

Methods: 148,173 individuals aged $\geq 35$ years were recruited in Mumbai during 1991-1997 and followed to ascertain vital status during 1997-2003. Subjects were divided according to educational status into one of the five groups: illiterate, primary school ( $\$ 5$ years of formal education), middle school (6-8 years), secondary school (9-10 years) and college (> 10 years). Multivariate analyses using Cox proportional hazard model was performed and hazard ratios (HRs) and 95\% confidence intervals (Cls) determined.
\end{abstract}

Results: At average follow-up of 5.5 years (774,129 person-years) 13,261 deaths were observed. CVD was the major cause of death in all the five educational groups. Age adjusted all-cause mortality per 100,000 in illiterate to college going men respectively was 2154, 2149, 1793, 1543 and 1187 and CVD mortality was 471, 654, 618, 518 and 450; and in women all-cause mortality was 1444, 949, 896, 981 and 962 and CVD mortality was 429, 301, 267, 426 and 317 ( $p_{\text {trend }}<0.01$ ). Compared with illiterate, age-adjusted HRs for CVD mortality in primary school to college going men were 1.36, 1.27, 1.01 and 0.88 ( $p_{\text {trend }}<0.05$ ) and in women 0.69, 0.55, 1.04 and 0.74, respectively ( $\left.p_{\text {trend }}>0.05\right)$.

Conclusions: Inverse association of literacy status with all-cause mortality was observed in Indian men and women, while, for CVD mortality it was observed only in men.

\section{Background}

Illiteracy and low educational status are highly prevalent in low income countries. It is well known that poverty is associated with greater ill health and mortality [1] and low educational status is a major determinant of disease as well as mortality [2]. Low educational status is associated with under-nutrition, greater infant and maternal mortality, and acute and chronic infections [1]. In high and middle income countries it is also associated with increased incidence and mortality from chronic diseases such as cardiovascular disease (CVD), chronic respiratory diseases and cancer $[2,3]$.

In developing countries CVDs (coronary heart disease and stroke) are considered to be more prevalent in higher socioeconomic status (SES) and more literate

\footnotetext{
* Correspondence: pednekarmangesh@healis.org

'Healis Sekhsaria Institute for Public Health, CBD Belapur, Navi Mumbai, Maharashtra-400614, India

Full list of author information is available at the end of the article
}

subjects [4]. Using the corollary of developed North American and Western European countries where the diseases were more frequent among the more literate subjects till 1960's and then became more in the less literate [4], it has been argued that the burden of CVDs could be shifting and could be more in the poor subjects in countries in economic transition such as India [5]. However, reliable national SES- or literacy-specific mortality statistics do not exist here. Many cardiovascular risk factor epidemiological studies in mid and late $20^{\text {th }}$ century have reported that the risk factors are more in upper SES subjects as compared to the poor [6], although some studies reported that risk factors could be more in poor especially where the problem of illiteracy is high [7]. Recent case-control studies have reported that SES, as measured by educational status, is inversely related to acute myocardial infarction $[8,9]$ and observational studies have reported that low SES subjects are more likely to die from acute coronary events

\section{() Biomed Central}


as compared to the rich [10]. To determine association of educational status as marker of SES with cardiovascular mortality we performed a prospective cohort epidemiological study in Mumbai, India.

\section{Methods}

Recruitment

The Mumbai Cohort Study was conducted in the main city of Mumbai (India), with mortality as the endpoint. A total of 148,173 persons aged $\geq 35$ years were recruited during 1991-1997. House-to-house interviews were conducted face-to-face using a structured questionnaire. Electoral rolls, organized by area with a polling station of 1,000-1,500 individuals as the smallest geographical unit, were used as the sampling frame. The electoral rolls provided name, age, sex, and address of all the individuals aged $\geq 18$ years. We excluded polling stations that served upper-middle-class and upper-class housing complexes because of security issues (i.e., they were essentially "gated communities"). For a selected polling station, all eligible people (aged $\geq 35$ years) listed on its electoral roll were interviewed in local languages (Marathi, Hindi) by trained field supervisors by using handheld computers (electronic diaries) but the information was recorded in English. The study satisfies all the criteria regarding the ethical treatment of human subjects, especially those formulated by the Indian Council of Medical Research (ICMR). This study was approved by independent institute review board (HealisIRB) formulated as per the guideline provided by ICMR (which confirmed to Helsinki declaration and to local legislation). Participatory oral consent was obtained from all participants at the time of recruitment. Details regarding the recruitment procedures and measurements have been published previously $[11,12]$.

\section{Data sources}

The baseline survey included the following components: 1) anthropometry to measure weight (using a bathroom scale that was calibrated to 100 gram amounts; staff recorded to the nearest kilogram) and height (using a specially constructed instrument consisting of a steel platform to which was attached a steel measuring tape that was calibrated to the nearest millimetre; staff recorded to the nearest $\mathrm{cm}$ ); and 2) Interviewer administered structured questionnaire [11-14]. For the present study, data regarding age, sex, education (as proxy for $\mathrm{SES}$ ), religion, mother tongue, height, weight, body mass index (BMI), and details on tobacco use were abstracted from the baseline data [11-14]. Subjects were classified according to their educational status into illiterate, primary school ( $\leq 5$ years of formal education), middle school (6-8 years), secondary school (9-10 years) and college (> 10 years). Subjects were also broadly classified as having never used tobacco, or being a current or former user of smokeless tobacco only, or being a current or former smoker only or both (includes those who smoke and use smokeless tobacco).

\section{Follow-up}

An active house-to-house follow-up was conducted on average 5.5 years after the baseline survey. The field supervisors were provided with the list of names and addresses of cohort members and were instructed to revisit each person. If the person was alive and available, a face-to-face re-interview was conducted. If the person was reported to have died, the date and place of death were recorded with extra questioning and care. Permanent migration, while the subject was alive, from the study area was considered as withdrawal from the study, and the date of migration was noted. The re-interviews were conducted during 1997-2003. The results of follow-up are shown in Figure 1 and additional file 1 as reported earlier [11-14].

\section{Cause of death}

The deaths recorded during the follow-up were linked with the dataset obtained from the municipal corporation death registers. In Mumbai, almost all the deaths are registered and medically certified. For matched deaths, the underlying cause of death was derived from the cause information copied from the corporation death registers and then coded according to the ICD-10 guidelines. Cause specific analyses were performed for various circulatory system related deaths (ICD-10 codes I00-99, will be referred as CVD here after) such as ischemic heart diseases (I20-25, referred as IHD) and cerebrovascular diseases (I60-69, referred as stroke). For 1685 randomly selected matched deaths, an independent field check was performed and matching was found to be nearly $100 \%$ accurate [11].

\section{Statistical analysis}

Methodological details regarding anthropometric measurements, and information collected from the structured questionnaire have been published [11-14]. Follow-up methodology has been reported [11]. Causes of deaths are reported in percent. Age-adjusted rates for all-cause, CVD, IHD and stroke mortality were determined separately for men and women and reported as deaths per 100,000 subjects. Adjusted survival curves have been plotted for various educational groups for allcause and CVDs. The association between various educational groups and all-cause, CVD, IHD, and stroke deaths are presented as hazard ratios (HRs) and 95\% confidence intervals (CIs) derived from multivariate Cox proportional hazards regression modelling using SPSS 13.0. The response variable, death, was coded as a 


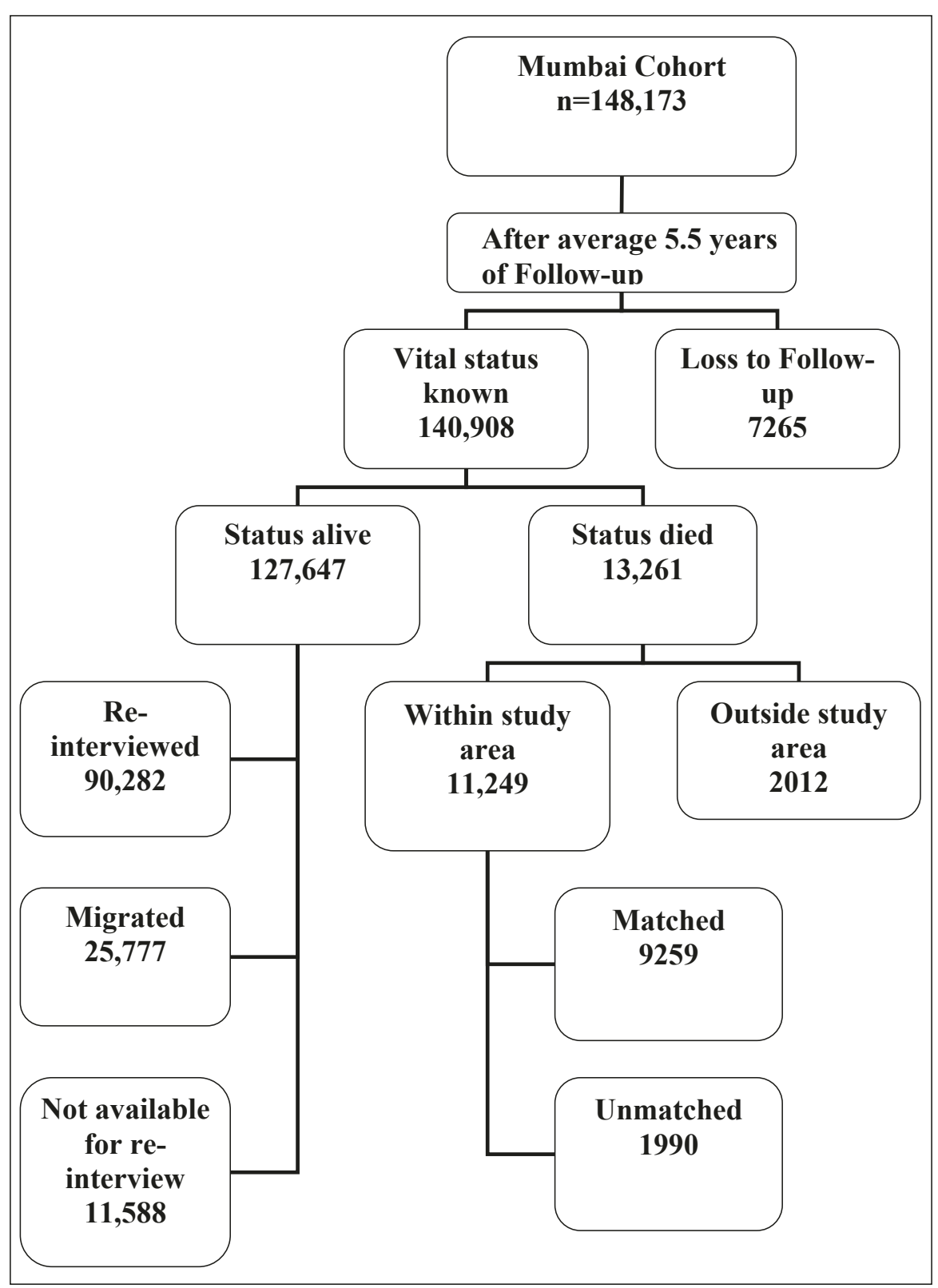

Figure 1 Flow diagram of house-to-house follow-up, Mumbai Cohort Study.

dichotomous variable, and the time to event or censoring was regarded as a continuous variable. Age, smoking or tobacco use and body mass index (BMI) were added to the model as independent variables using stepwise regression analyses. Adjusted HRs and 95\% CIs were estimated separately for men and women. A population attributable fraction (PAF) [11] was calculated using a formula $\sum \mathrm{pd}_{\mathrm{i}}\left(\mathrm{RR}_{\mathrm{i}}-1\right) / \mathrm{RR}_{\mathrm{i}}$, where ' $\mathrm{pd}_{\mathrm{i}}$ ' represents the proportion of the total deaths in the population arising from the $i^{\text {th }}$ exposure category and $R R_{i}$ is the (adjusted) $\mathrm{RR}$ for the $\mathrm{i}^{\text {th }}$ exposure category (relative to the reference or unexposed stratum).

\section{Results}

Baseline characteristics of the study subjects are shown in Table 1 . There were 88,658 men and 59,515 women in the cohort. Most of the subjects were in age-groups 45 59 years. Illiteracy was more among women $(45.3 \%)$ than men $(17.0 \%)$. Only $15.8 \%$ men and $5.9 \%$ women had more than secondary level education. High prevalence of overweight or obesity (BMI $\geq 25 \mathrm{~kg} / \mathrm{m}^{2}$ ) was also observed in both men (20.2\%) and women (29.4\%). Prevalence of any tobacco use was also high (men $69.9 \%$ and women $59.7 \%$ ). Around $80 \%$ subjects were Hindu while over $60 \%$ reported Marathi as their mother tongue. 
Table 1 Demographic details of the study subjects by educational status*for men, Mumbai Cohort Study, Mumbai, Maharashtra, India

\begin{tabular}{|c|c|c|c|c|c|c|}
\hline Men & $\begin{array}{l}\text { Illiterate } \\
(n=15091)\end{array}$ & $\begin{array}{l}\text { Primary school } \\
(\mathrm{n}=33549)\end{array}$ & $\begin{array}{l}\text { Middle school } \\
(n=26075)\end{array}$ & $\begin{array}{l}\text { Secondary school } \\
(\mathrm{n}=8308)\end{array}$ & $\begin{array}{l}\text { College } \\
(n=5635)\end{array}$ & $\begin{array}{l}\text { Total } \\
(\mathrm{N}=88658)\end{array}$ \\
\hline \multicolumn{7}{|l|}{ Age groups } \\
\hline 35 to 39 & $3.9 \%$ & $7.5 \%$ & $13.2 \%$ & $13.6 \%$ & $12.1 \%$ & $9.4 \%$ \\
\hline 40 to 44 & $3.9 \%$ & $7.0 \%$ & $10.2 \%$ & $11.3 \%$ & $9.1 \%$ & $7.9 \%$ \\
\hline 45 to 49 & $24.4 \%$ & $23.1 \%$ & $30.3 \%$ & $33.1 \%$ & $29.0 \%$ & $26.7 \%$ \\
\hline 50 to 54 & $18.6 \%$ & $15.6 \%$ & $16.1 \%$ & $15.1 \%$ & $14.3 \%$ & $16.1 \%$ \\
\hline 55 to 59 & $13.8 \%$ & $13.1 \%$ & $10.9 \%$ & $10.0 \%$ & $11.3 \%$ & $12.2 \%$ \\
\hline 60 to 64 & $14.6 \%$ & $12.6 \%$ & $8.8 \%$ & $6.7 \%$ & $9.3 \%$ & $11.1 \%$ \\
\hline 65 to 69 & $9.2 \%$ & $9.5 \%$ & $5.3 \%$ & $4.9 \%$ & $6.5 \%$ & $7.6 \%$ \\
\hline 70 \& up & $11.5 \%$ & $11.6 \%$ & $5.3 \%$ & $5.3 \%$ & $8.3 \%$ & $8.9 \%$ \\
\hline \multicolumn{7}{|l|}{ Religion } \\
\hline Hindu & $68.5 \%$ & $77.1 \%$ & $79.1 \%$ & $81.9 \%$ & $79.6 \%$ & $76.8 \%$ \\
\hline Muslim & $25.7 \%$ & $15.4 \%$ & $14.1 \%$ & $8.4 \%$ & $14.1 \%$ & $16.0 \%$ \\
\hline Buddhist & $4.7 \%$ & $4.8 \%$ & $3.6 \%$ & $4.3 \%$ & $1.8 \%$ & $4.2 \%$ \\
\hline Christian & $1.0 \%$ & $2.4 \%$ & $2.8 \%$ & $4.1 \%$ & $3.4 \%$ & $2.5 \%$ \\
\hline Others & $0.2 \%$ & $0.3 \%$ & $0.3 \%$ & $1.3 \%$ & $1.1 \%$ & $0.4 \%$ \\
\hline \multicolumn{7}{|l|}{ Mother tongue } \\
\hline Marathi & $37.1 \%$ & $57.9 \%$ & $59.1 \%$ & $69.5 \%$ & $53.4 \%$ & $55.5 \%$ \\
\hline Hindi & $34.2 \%$ & $13.8 \%$ & $15.2 \%$ & $8.1 \%$ & $9.8 \%$ & $16.9 \%$ \\
\hline Gujarati & $4.2 \%$ & $10.2 \%$ & $11.1 \%$ & $6.2 \%$ & $19.1 \%$ & $9.6 \%$ \\
\hline Urdu & $13.1 \%$ & $9.4 \%$ & $6.6 \%$ & $6.9 \%$ & $7.6 \%$ & $8.9 \%$ \\
\hline South Indian & $11.3 \%$ & $8.5 \%$ & $7.8 \%$ & $8.9 \%$ & $9.9 \%$ & $8.9 \%$ \\
\hline Others & $0.2 \%$ & $0.1 \%$ & $0.2 \%$ & $0.5 \%$ & $0.1 \%$ & $0.2 \%$ \\
\hline \multicolumn{7}{|l|}{$\mathrm{BMI}^{* *}\left(\mathrm{~kg} / \mathrm{m}^{2}\right)$} \\
\hline Normal & $64.1 \%$ & $62.3 \%$ & $61.7 \%$ & $63.3 \%$ & $60.3 \%$ & $62.4 \%$ \\
\hline Thin & $12.9 \%$ & $10.1 \%$ & $7.7 \%$ & $6.0 \%$ & $4.7 \%$ & $9.2 \%$ \\
\hline Very Thin & $5.1 \%$ & $4.6 \%$ & $3.5 \%$ & $2.5 \%$ & $1.5 \%$ & $3.9 \%$ \\
\hline Extremely Thin & $5.5 \%$ & $5.1 \%$ & $3.7 \%$ & $2.8 \%$ & $1.6 \%$ & $4.3 \%$ \\
\hline Overweight & $10.9 \%$ & $15.7 \%$ & $20.2 \%$ & $22.4 \%$ & $26.7 \%$ & $17.5 \%$ \\
\hline Obese & $1.5 \%$ & $2.3 \%$ & $3.2 \%$ & $3.0 \%$ & $5.2 \%$ & $2.7 \%$ \\
\hline \multicolumn{7}{|c|}{ Tobacco usage } \\
\hline Never-user & $21.6 \%$ & $23.8 \%$ & $35.5 \%$ & $37.3 \%$ & $55.2 \%$ & $30.1 \%$ \\
\hline Smokeless & $39.9 \%$ & $42.8 \%$ & $37.0 \%$ & $35.3 \%$ & $20.3 \%$ & $38.5 \%$ \\
\hline Smoker & $14.8 \%$ & $18.6 \%$ & $14.0 \%$ & $17.5 \%$ & $17.1 \%$ & $16.4 \%$ \\
\hline Both*** & $23.8 \%$ & $14.8 \%$ & $13.5 \%$ & $10.0 \%$ & $7.5 \%$ & $15.0 \%$ \\
\hline Women & $\begin{array}{l}\text { Illiterate } \\
(n=26959)\end{array}$ & $\begin{array}{l}\text { Primary school } \\
(n=20850)\end{array}$ & $\begin{array}{l}\text { Middle school } \\
(n=8196)\end{array}$ & $\begin{array}{l}\text { Secondary school } \\
(n=2536)\end{array}$ & $\begin{array}{l}\text { College } \\
(n=974)\end{array}$ & $\begin{array}{l}\text { Total } \\
(\mathrm{N}=59515)\end{array}$ \\
\hline \multicolumn{7}{|l|}{ Age groups } \\
\hline 35 to 39 & $14.6 \%$ & $27.4 \%$ & $42.7 \%$ & $47.5 \%$ & $44.4 \%$ & $24.8 \%$ \\
\hline 40 to 44 & $12.9 \%$ & $19.2 \%$ & $22.5 \%$ & $20.0 \%$ & $22.4 \%$ & $16.9 \%$ \\
\hline 45 to 49 & $14.9 \%$ & $16.9 \%$ & $14.4 \%$ & $11.4 \%$ & $11.3 \%$ & $15.4 \%$ \\
\hline 50 to 54 & $15.6 \%$ & $12.8 \%$ & $9.5 \%$ & $7.8 \%$ & $8.1 \%$ & $13.3 \%$ \\
\hline 55 to 59 & $12.5 \%$ & $9.0 \%$ & $5.6 \%$ & $5.3 \%$ & $5.1 \%$ & $9.9 \%$ \\
\hline 60 to 64 & $13.1 \%$ & $7.3 \%$ & $3.1 \%$ & $4.6 \%$ & $4.5 \%$ & $9.2 \%$ \\
\hline 65 to 69 & $7.4 \%$ & $4.0 \%$ & $1.4 \%$ & $2.1 \%$ & $2.4 \%$ & $5.1 \%$ \\
\hline $70 \&$ up & $8.9 \%$ & $3.5 \%$ & $0.9 \%$ & $1.3 \%$ & $1.8 \%$ & $5.5 \%$ \\
\hline \multicolumn{7}{|l|}{ Religion } \\
\hline Hindu & $79.2 \%$ & $83.8 \%$ & $85.6 \%$ & $84.1 \%$ & $85.9 \%$ & $82.0 \%$ \\
\hline Muslim & $8.0 \%$ & $5.6 \%$ & $5.9 \%$ & $4.1 \%$ & $3.6 \%$ & $6.7 \%$ \\
\hline Buddhist & $11.4 \%$ & $5.2 \%$ & $3.7 \%$ & $3.0 \%$ & $1.1 \%$ & $7.6 \%$ \\
\hline
\end{tabular}


Table 1 Demographic details of the study subjects by educational status*for men, Mumbai Cohort Study, Mumbai, Maharashtra, India (Continued)

\begin{tabular}{|c|c|c|c|c|c|c|}
\hline Christian & $1.2 \%$ & $4.7 \%$ & $4.3 \%$ & $7.1 \%$ & $5.5 \%$ & $3.1 \%$ \\
\hline Others & $0.2 \%$ & $0.7 \%$ & $0.5 \%$ & $1.7 \%$ & $3.8 \%$ & $0.6 \%$ \\
\hline \multicolumn{7}{|l|}{ Mother tongue } \\
\hline Marathi & $74.2 \%$ & $75.6 \%$ & $78.9 \%$ & $74.7 \%$ & $70.6 \%$ & $75.3 \%$ \\
\hline Hindi & $10.0 \%$ & $4.0 \%$ & $6.1 \%$ & $1.8 \%$ & $4.9 \%$ & $6.9 \%$ \\
\hline Gujarati & $4.7 \%$ & $6.9 \%$ & $4.1 \%$ & $6.0 \%$ & $8.2 \%$ & $5.5 \%$ \\
\hline Urdu & $4.0 \%$ & $4.0 \%$ & $2.4 \%$ & $3.4 \%$ & $2.7 \%$ & $3.8 \%$ \\
\hline South Indian & $6.7 \%$ & $9.1 \%$ & $7.7 \%$ & $12.6 \%$ & $13.0 \%$ & $8.0 \%$ \\
\hline Others & $0.4 \%$ & $0.3 \%$ & $0.9 \%$ & $1.5 \%$ & $0.5 \%$ & $0.5 \%$ \\
\hline \multicolumn{7}{|l|}{$\overline{B M I * *}\left(\mathrm{~kg} / \mathrm{m}^{2}\right)$} \\
\hline Normal & $52.4 \%$ & $50.5 \%$ & $50.1 \%$ & $52.3 \%$ & $48.0 \%$ & $51.4 \%$ \\
\hline Thin & $11.2 \%$ & $7.6 \%$ & $7.7 \%$ & $5.8 \%$ & $4.1 \%$ & $9.1 \%$ \\
\hline Very Thin & $5.4 \%$ & $3.4 \%$ & $3.9 \%$ & $3.3 \%$ & $1.4 \%$ & $4.3 \%$ \\
\hline Extremely Thin & $7.8 \%$ & $4.3 \%$ & $4.2 \%$ & $2.5 \%$ & $1.5 \%$ & $5.7 \%$ \\
\hline Overweight & $18.0 \%$ & $25.8 \%$ & $25.9 \%$ & $27.8 \%$ & $34.4 \%$ & $22.5 \%$ \\
\hline Obese & $5.1 \%$ & $8.4 \%$ & $8.2 \%$ & $8.3 \%$ & $10.5 \%$ & $6.9 \%$ \\
\hline \multicolumn{7}{|l|}{ Tobacco usage } \\
\hline Never-user & $25.4 \%$ & $45.8 \%$ & $58.6 \%$ & $74.0 \%$ & $89.3 \%$ & $40.3 \%$ \\
\hline Smokeless & $73.8 \%$ & $53.9 \%$ & $41.3 \%$ & $25.9 \%$ & $10.5 \%$ & $59.3 \%$ \\
\hline Smoker & $0.4 \%$ & $0.2 \%$ & $0.1 \%$ & $0.1 \%$ & $0.2 \%$ & $0.3 \%$ \\
\hline Both*** & $0.3 \%$ & $0.1 \%$ & $0.1 \%$ & $0.0 \%$ & & $0.2 \%$ \\
\hline
\end{tabular}

*Illiterate, Primary school ( $\leq 5$ years of formal education), Middle school (6-8 years), Secondary school (9-10 years) and College ( $>10$ years)

**BMI body mass index = weight $(\mathrm{kg}) /$ height $(\mathrm{m})^{2} ; \mathrm{BMI}(\mathrm{kg} / \mathrm{m} 2)$ categories were defined as follows: extremely thin $(<16.0)$; very thin $(16.0$ to $<17.0)$; thin $(17.0$ to $<18.5)$; normal $(18.5$ to $<25.0)$; overweight $(25.0$ to $<30.0)$; and obese $(\geq 30.0)$

***includes those who smoke and use smokeless tobacco

During follow-up, of the total recruited subjects 7265 could not be traced; the most common reason was the demolition of their residential buildings (6452 subjects). No differences in baseline variables were observed in subjects whose data were available as compared to those lost to follow-up (additional file 1). Among the remaining 140,908 subjects, 13,261 (9.4\%) persons died while 127,647 were alive (of which 25,777 subjects had migrated outside study area) at the end of follow-up period. Of the total 13,261 deaths, 11,249 died within study area and among those died within study area 9259 deaths $(72.3 \%)$ were matched and coded using ICD-10 (Figure 1). Details regarding the matching and coding of underlying causes of deaths published elsewhere [11-14]. For 260 deaths date of expiry was found to precede the date of recruitment; hence these subjects were excluded. Detailed investigation of a sample of these deaths revealed that the deaths had occurred very close to the date of recruitment of these subjects. Thus only 13,001 deaths were available for final analysis.

The subjects were followed for a mean of 5.5 years and 774,129 person-years were observed. The major causes of deaths in different educational groups are shown in Table 2. CVDs were the largest proportion of cause of death in men and women across all the educational groups. Age adjusted all-cause mortality per 100,000 in men for different educational groups was 2154 in illiterate, 2149 in primary school, 1793 in middle school, 1543 in secondary school and 1187 in college and in women it was 1444, 949, 896, 981 and 962, respectively. In different educational groups CVD mortality was $471,654,618,518$ and 450 in men and 429, 301, 267, 426 and 317 in women; IHD mortality was 234, 371, 401, 349 and 338 in men and 180, 133, 131, 227 and 96 in women and stroke mortality was 124 , $135,107,59$ and 31 in men and 87, 67, 58, 47 and 50 in women.

Adjusted survival curves for all-cause and CVD mortality in men and women for different educational groups are shown in Figure 2. In men the greatest mortality was observed in illiterate and primary school men with better survival in more literate groups while in women no such clear associations was observed. Crude and adjusted HRs and 95\% CIs for all-cause, CVD, IHD and stroke mortality are shown in Tables 3 (men) and 4 (women). All-cause mortality was highest in illiterate men and women and was used as a reference category for estimating HRs throughout the analysis. Compared to illiterate, the age-adjusted HRs were lower in other groups in men $(1.00,0.84,0.71$ and 0.55$)$ as well as in 
Table 2 Major causes of death (\% of total deaths) in various educational groups*, Mumbai Cohort Study, Mumbai, Maharashtra, India

\begin{tabular}{|c|c|c|c|c|c|}
\hline Men & Illiterate & Primary school & Middle school & Secondary school & College \\
\hline Number of deaths & 1904 & 4507 & 2197 & 597 & 384 \\
\hline Major causes of death (column \%) & $\begin{array}{c}\text { Cardiovascular } \\
(23.5) \\
\text { Respiratory } \\
(10.8) \\
\text { Other medical } \\
\text { (10.4) } \\
\text { Tuberculosis } \\
\text { (7.4) } \\
\text { Cancer } \\
(4.2)\end{array}$ & $\begin{array}{c}\text { Cardiovascular } \\
(32.5) \\
\text { Other medical } \\
(11.0) \\
\text { Respiratory } \\
\text { (9.1) } \\
\text { Tuberculosis } \\
\text { (7.5) } \\
\text { Cancer } \\
\text { (5.9) }\end{array}$ & $\begin{array}{c}\text { Cardiovascular } \\
(33.5) \\
\text { Other medical } \\
(10.8) \\
\text { Respiratory } \\
\text { (8.6) } \\
\text { Tuberculosis } \\
\text { (7.4) } \\
\text { Cancer } \\
\text { (6.1) }\end{array}$ & $\begin{array}{c}\text { Cardiovascular } \\
\text { (31.3) } \\
\text { Other medical } \\
(12.9) \\
\text { Tuberculosis } \\
\text { (8.4) } \\
\text { Cancer } \\
(7.0) \\
\text { Respiratory } \\
(6.7)\end{array}$ & $\begin{array}{c}\text { Cardiovascular } \\
\text { (38.0) } \\
\text { Other medical } \\
(9.4) \\
\text { Cancer } \\
(7.8) \\
\text { Tuberculosis } \\
\text { (5.2) } \\
\text { Respiratory } \\
(4.4)\end{array}$ \\
\hline Women & Illiterate & Primary school & Middle school & Secondary school & College \\
\hline Number of deaths & 2417 & 762 & 160 & 54 & 19 \\
\hline Major causes of death (column \%) & $\begin{array}{c}\text { Cardiovascular } \\
\text { (29.8) } \\
\text { Other medical } \\
(14.0) \\
\text { Respiratory } \\
\text { (13.4) } \\
\text { Tuberculosis } \\
\text { (5.7) } \\
\text { Cancer } \\
\text { (4.5) }\end{array}$ & $\begin{array}{c}\text { Cardiovascular } \\
(30.7) \\
\text { Other medical } \\
(15.1) \\
\text { Tuberculosis } \\
(10.6) \\
\text { Respiratory } \\
\text { (7.6) } \\
\text { Cancer } \\
(6.0)\end{array}$ & $\begin{array}{c}\text { Cardiovascular } \\
(24.4) \\
\text { Other medical } \\
(14.4) \\
\text { Tuberculosis } \\
(11.3) \\
\text { Respiratory } \\
(10.0) \\
\text { Cancer } \\
\text { (9.4) }\end{array}$ & $\begin{array}{c}\text { Cardiovascular } \\
(44.4) \\
\text { Other medical } \\
\text { (18.5) } \\
\text { Tuberculosis } \\
\text { (9.3) } \\
\text { Respiratory } \\
\text { (5.6) } \\
\text { Cancer } \\
\text { (3.7) }\end{array}$ & $\begin{array}{c}\text { Cardiovascular } \\
\text { (36.8) } \\
\text { Tuberculosis } \\
\text { (15.8) } \\
\text { Cancer } \\
\text { (10.5) } \\
\text { Respiratory } \\
\text { (5.3) } \\
\text { Other medica } \\
\text { (5.3) }\end{array}$ \\
\hline
\end{tabular}

*Illiterate, Primary school ( $\leq 5$ years of formal education), Middle school (6-8 years), Secondary school (9-10 years) and College ( $>10$ years)

women $(0.68,0.61,0.64$ and 0.57$)$ with a significant negative trends $(\mathrm{p}<0.001)$. For CVD mortality age adjusted HRs were higher in primary as well middle school men than illiterates (Table 3); in contrast, it was lower in women (Table 4). Most literate (> 10 years of formal education, i.e. college) men and women had the lowest CVD mortality (Table 3, 4). Multivariate adjustment for other available confounders such as various forms of tobacco use, BMI, religion and mother tongue attenuated HRs but did not nullify the association for all-cause as well as CVD mortality in men and women.

\section{Discussion}

This study shows that there is significant inverse association of literacy status with all-cause mortality in urban Indian men and women. In men the CVD mortality is also significantly greater in low educational status subjects while the association is not clear in women. The association of education and mortality (all-cause, CVD, IHD, and stroke) in both men and women appears to be influenced mainly by age, followed by tobacco usage and body mass index (surrogate for lipid and glucose metabolism abnormalities), religion, and mother tongue. The policy implication from this study could be improving the educational status may results in preventing $\sim 9 \%$ premature male and female deaths in developing country populations such as in India.

Bertrand Russell almost a century ago highlighted the importance of education as catalyst of society's well being [15]. For the last 50 years, studies from developed countries have consistently reported that subjects with illiteracy and low educational status have greater allcause, chronic disease as well as cardiovascular mortality [16-21]. Studies from developed countries have also reported that greater literacy is associated with better uptake of preventive lifestyles, lower prevalence of risk factors, early diagnosis and management of chronic disease risk factors, better quality of acute disease treatment, and better long-term treatment and compliance $[22,23]$. All these lead to lower incidence of CVD and lower short- and long-term mortality. Studies from developing countries are not clear on association of cardiovascular mortality or risk factors [5,7,24-28]. The present study shows that the more literate men had lower mortality from CVD. Greater CVD mortality among the less educated subjects could also be due to poor quality management and control of risk factors and, indeed, we have reported that status of hypertension awareness among this cohort is dismal (less than $10 \%$ awareness) indicating poor health literacy, poor control of risk factors and possibly greater event rates and mortality [29].

This study has multiple limitations and strengths. We obtained cause of death information from local death registries. Cause-of-death registries are often imprecise in India and this could be important in our study. On the other hand, the Mumbai registry is one of the oldest and most efficient systems of mortality ascertainment and thus the data are the best from this country [11]. We also validated the ascertainment of the causes of 


\section{All-cause mortality}
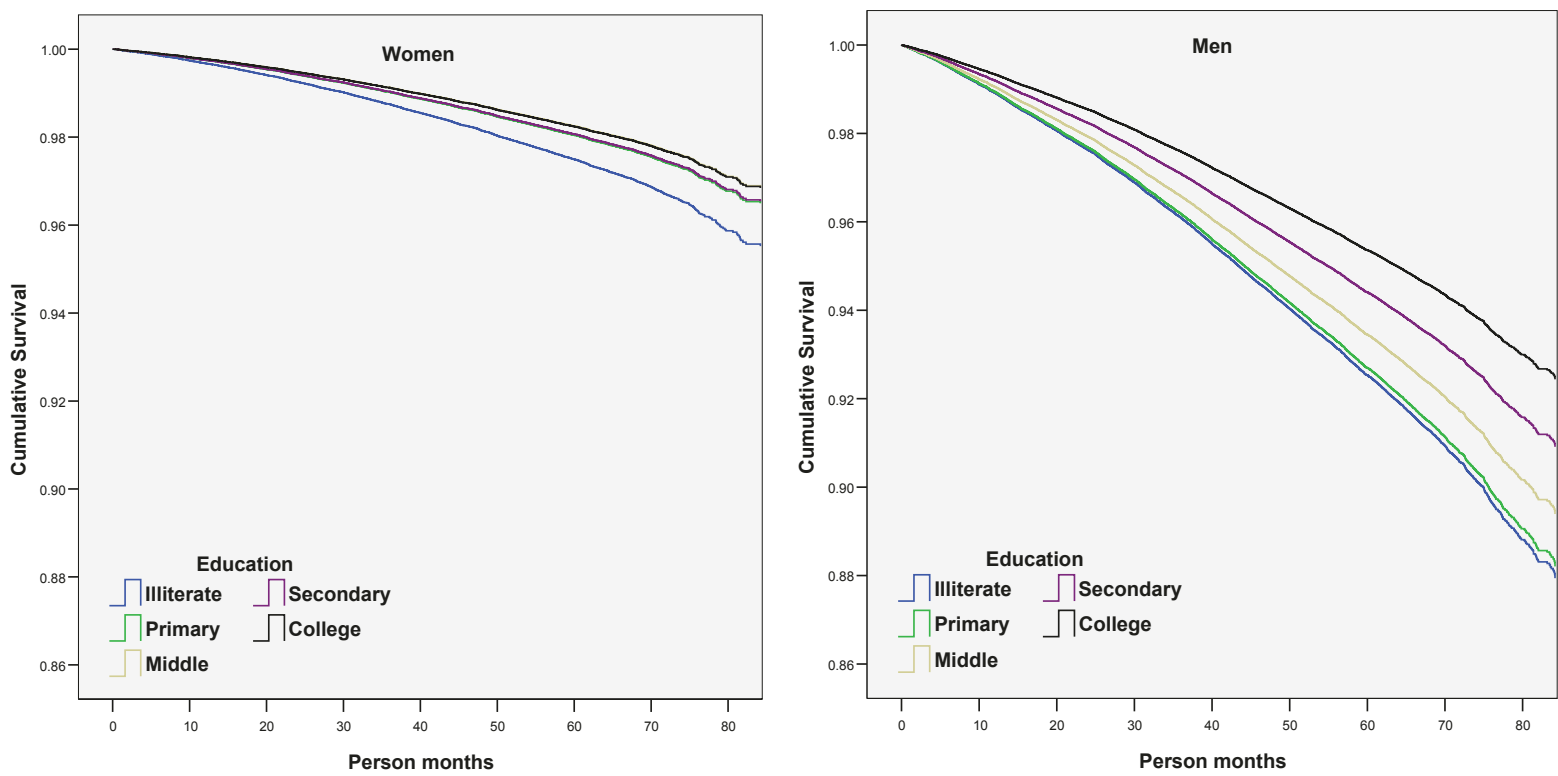

CVD
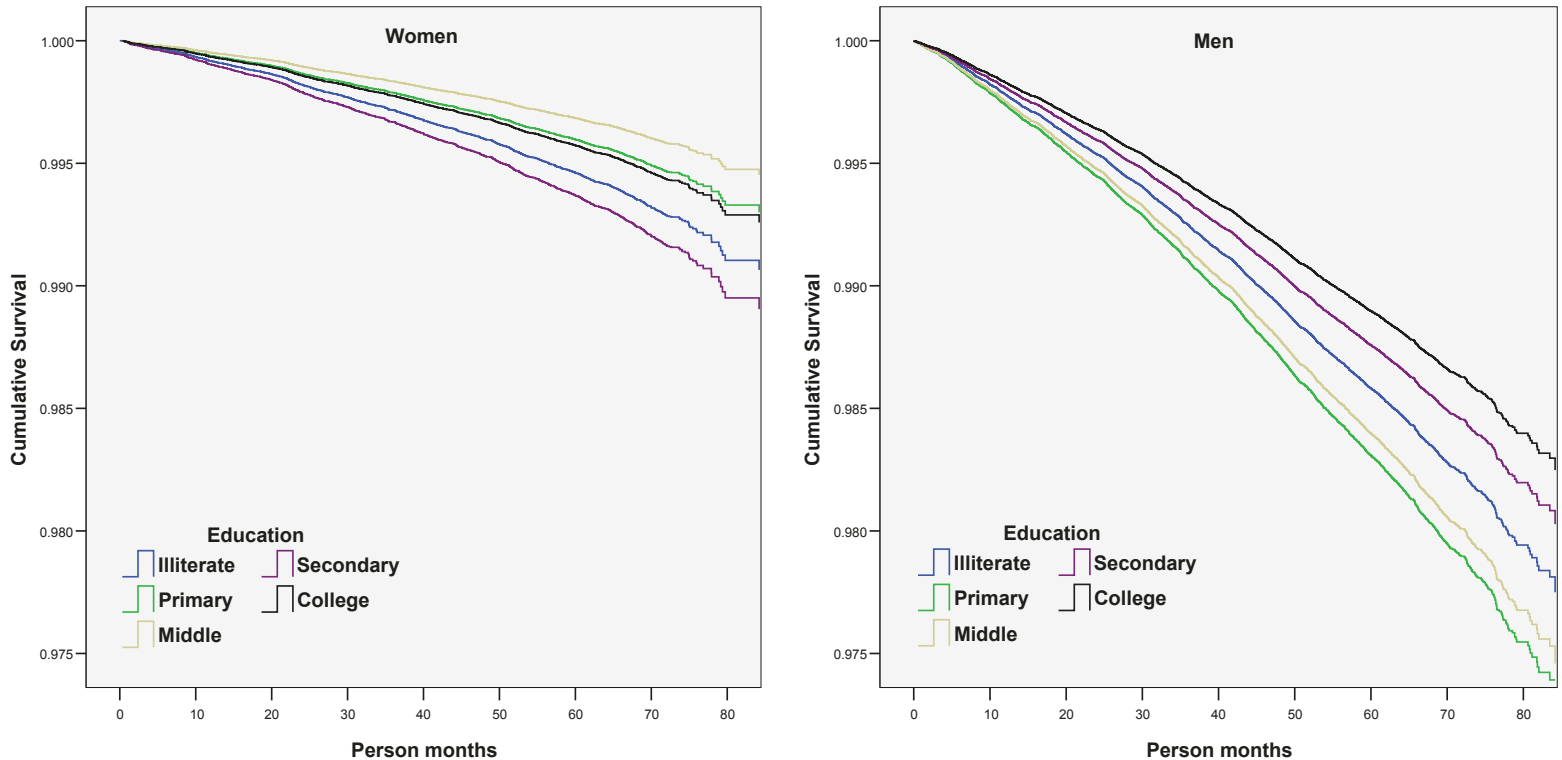

Figure 2 Multivariate adjusted survival curves for all-cause and CVD mortality, Mumbai Cohort Study

death in a random sub-sample with physician-defined cause and the results were consistent. Secondly, preexisting diseases and drug therapy can substantially influence mortality from communicable as well as noncommunicable diseases such as CVD and we have no data on them. One way to exclude significant pre-existing morbid conditions is to analyse data after exclusion of deaths in the first two years, but we were not able to perform such analyses due to fewer number of deaths were observed in more literate groups. Moreover, such 
Table 3 Person years, number of deaths, hazard ratios (HRs) and 95\% confidence intervals (Cls) for all-cause, CVD, IHD and stroke mortality in men stratified by educational groups*, Mumbai Cohort Study, Mumbai, Maharashtra, India

\begin{tabular}{|c|c|c|c|c|c|}
\hline Men & Illiterate & Primary school & Middle school & Secondary school & College \\
\hline Person years & 69,064 & 165,757 & 135,193 & 44,003 & 29,876 \\
\hline All-deaths (n) & 1904 & 4507 & 2197 & 597 & 384 \\
\hline Death rates per $100000^{2}$ & 2154 & 2149 & 1793 & 1543 & 1187 \\
\hline $\begin{array}{l}\mathrm{HR}^{1} \\
95 \% \mathrm{Cl}\end{array}$ & 1.0 & $\begin{array}{c}0.98 \\
(0.93-1.03)\end{array}$ & $\begin{array}{c}0.58 \\
(0.55-0.62)\end{array}$ & $\begin{array}{c}0.48 \\
(0.44-0.53)\end{array}$ & $\begin{array}{c}0.46 \\
(0.41-0.51)\end{array}$ \\
\hline $\begin{array}{l}\mathrm{HR}^{2} \\
95 \% \mathrm{Cl}\end{array}$ & 1.0 & $\begin{array}{c}1.00 \\
(0.95-1.06)\end{array}$ & $\begin{array}{c}0.84 \\
(0.79-0.89)\end{array}$ & $\begin{array}{c}0.71 \\
(0.65-0.78)\end{array}$ & $\begin{array}{c}0.55 \\
(0.50-0.62)\end{array}$ \\
\hline $\begin{array}{l}\mathrm{HR}^{3} \\
95 \% \mathrm{Cl}\end{array}$ & 1.0 & $\begin{array}{c}1.02 \\
(0.97-1.08)\end{array}$ & $\begin{array}{c}0.89 \\
(0.83-0.94)\end{array}$ & $\begin{array}{c}0.75 \\
(0.68-0.82)\end{array}$ & $\begin{array}{c}0.60 \\
(0.54-0.67)\end{array}$ \\
\hline $\begin{array}{l}\mathrm{HR}^{4} \\
95 \% \mathrm{Cl}\end{array}$ & 1.0 & $\begin{array}{c}0.98 \\
(0.92-1.03)\end{array}$ & $\begin{array}{c}0.87 \\
(0.82-0.93)\end{array}$ & $\begin{array}{c}0.74 \\
(0.67-0.82)\end{array}$ & $\begin{array}{c}0.61 \\
(0.55-0.69)\end{array}$ \\
\hline $\mathrm{CVD}^{5}$ deaths $(\mathrm{n})$ & 448 & 1465 & 737 & 187 & 146 \\
\hline Death rates per $100000^{2}$ & 471 & 654 & 618 & 518 & 450 \\
\hline $\begin{array}{l}\mathrm{HR}^{1} \\
95 \% \mathrm{Cl}\end{array}$ & 1.0 & $\begin{array}{c}1.33 \\
(1.20-1.48)\end{array}$ & $\begin{array}{c}0.80 \\
(0.71-0.90)\end{array}$ & $\begin{array}{c}0.62 \\
(0.52-0.73)\end{array}$ & $\begin{array}{c}0.71 \\
(0.59-0.85)\end{array}$ \\
\hline $\begin{array}{l}\mathrm{HR}^{2} \\
95 \% \mathrm{Cl}\end{array}$ & 1.0 & $\begin{array}{c}1.36 \\
(1.22-1.51)\end{array}$ & $\begin{array}{c}1.27 \\
(1.13-1.43)\end{array}$ & $\begin{array}{c}1.01 \\
(0.85-1.19)\end{array}$ & $\begin{array}{c}0.88 \\
(0.73-1.06)\end{array}$ \\
\hline $\begin{array}{l}\mathrm{HR}^{3} \\
95 \% \mathrm{Cl}\end{array}$ & 1.0 & $\begin{array}{c}1.37 \\
(1.23-1.52)\end{array}$ & $\begin{array}{c}1.30 \\
(1.16-1.47)\end{array}$ & $\begin{array}{c}1.02 \\
(0.86-1.22)\end{array}$ & $\begin{array}{c}0.90 \\
(0.74-1.09)\end{array}$ \\
\hline $\begin{array}{l}\mathrm{HR}^{4} \\
95 \% \mathrm{Cl}\end{array}$ & 1.0 & $\begin{array}{c}1.20 \\
(1.07-1.33)\end{array}$ & $\begin{array}{c}1.13 \\
(1.00-1.28)\end{array}$ & $\begin{array}{c}0.88 \\
(0.73-1.04)\end{array}$ & $\begin{array}{c}0.78 \\
(0.64-0.94)\end{array}$ \\
\hline IHD ${ }^{6}$ deaths (n) & 223 & 835 & 481 & 125 & 109 \\
\hline Death rates per $100000^{2}$ & 234 & 371 & 401 & 349 & 338 \\
\hline $\begin{array}{l}\mathrm{HR}^{1} \\
95 \% \mathrm{Cl}\end{array}$ & 1.0 & $\begin{array}{c}1.53 \\
(1.32-1.78)\end{array}$ & $\begin{array}{c}1.05 \\
(0.89-1.23)\end{array}$ & $\begin{array}{c}0.83 \\
(0.66-1.03)\end{array}$ & $\begin{array}{c}1.06 \\
(0.84-1.33)\end{array}$ \\
\hline $\begin{array}{l}\mathrm{HR}^{2} \\
95 \% \mathrm{Cl}\end{array}$ & 1.0 & $\begin{array}{c}1.57 \\
(1.36-1.82)\end{array}$ & $\begin{array}{c}1.67 \\
(1.42-1.96)\end{array}$ & $\begin{array}{c}1.35 \\
(1.08-1.68)\end{array}$ & $\begin{array}{c}1.31 \\
(1.04-1.64)\end{array}$ \\
\hline $\begin{array}{l}\mathrm{HR}^{3} \\
95 \% \mathrm{Cl}\end{array}$ & 1.0 & $\begin{array}{c}1.58 \\
(1.37-1.84)\end{array}$ & $\begin{array}{c}1.71 \\
(1.45-2.00)\end{array}$ & $\begin{array}{c}1.36 \\
(1.09-1.70)\end{array}$ & $\begin{array}{c}1.32 \\
(1.04-1.66)\end{array}$ \\
\hline $\begin{array}{l}\mathrm{HR}^{4} \\
95 \% \mathrm{Cl}\end{array}$ & 1.0 & $\begin{array}{c}1.35 \\
(1.16-1.57)\end{array}$ & $\begin{array}{c}1.44 \\
(1.22-1.70)\end{array}$ & $\begin{array}{c}1.16 \\
(0.93-1.46)\end{array}$ & $\begin{array}{c}1.11 \\
(0.87-1.40)\end{array}$ \\
\hline Stroke ${ }^{7}$ deaths (n) & 115 & 303 & 126 & 22 & 10 \\
\hline Death rates per $100000^{2}$ & 124 & 135 & 107 & 59 & 31 \\
\hline $\begin{array}{l}\mathrm{HR}^{1} \\
95 \% \mathrm{Cl}\end{array}$ & 1.0 & $\begin{array}{c}1.08 \\
(0.87-1.34)\end{array}$ & $\begin{array}{c}0.53 \\
(0.41-0.68)\end{array}$ & $\begin{array}{c}0.28 \\
(0.18-0.45)\end{array}$ & $\begin{array}{c}0.19 \\
(0.10-0.36)\end{array}$ \\
\hline $\begin{array}{l}\mathrm{HR}^{2} \\
95 \% \mathrm{Cl}\end{array}$ & 1.0 & $\begin{array}{c}1.12 \\
(0.90-1.39)\end{array}$ & $\begin{array}{c}0.86 \\
(0.67-1.11)\end{array}$ & $\begin{array}{c}0.47 \\
(0.30-0.74)\end{array}$ & $\begin{array}{c}0.24 \\
(0.12-0.45)\end{array}$ \\
\hline $\begin{array}{l}\mathrm{HR}^{3} \\
95 \% \mathrm{Cl}\end{array}$ & 1.0 & $\begin{array}{c}1.13 \\
(0.91-1.40)\end{array}$ & $\begin{array}{c}0.90 \\
(0.70-1.16)\end{array}$ & $\begin{array}{c}0.50 \\
(0.32-0.79)\end{array}$ & $\begin{array}{c}0.27 \\
(0.14-0.51)\end{array}$ \\
\hline $\begin{array}{l}\mathrm{HR}^{4} \\
95 \% \mathrm{Cl}\end{array}$ & 1.0 & $\begin{array}{c}1.01 \\
(0.81-1.25)\end{array}$ & $\begin{array}{c}0.80 \\
(0.62-1.04)\end{array}$ & $\begin{array}{c}0.41 \\
(0.26-0.66)\end{array}$ & $\begin{array}{c}0.23 \\
(0.12-0.44)\end{array}$ \\
\hline
\end{tabular}

* Illiterate, Primary school ( $\leq 5$ years of formal education), Middle school (6-8 years), Secondary school (9-10 years) and College (> 10 years)

${ }^{1}$ crude hazard ratios (HRs), ${ }^{2}$ adjusted for age, ${ }^{3}$ adjusted for age and tobacco use, ${ }^{4}$ adjusted for age, tobacco use, BMl, religion and mother tongue, ${ }^{5}$ all circulatory system related deaths (ICD-10 codes 100-99), ${ }^{6}$ Ischemic Heart Disease deaths (I20-25), ${ }^{7}$ cerebrovascular deaths (I60-69).

analyses are more relevant to assess smoking- or BMIrelated mortality which has been published earlier $[11,14,30]$ but not the focus of the present study. The present study may have over-estimated the communicable diseases mortality which is likely to pre-exist. Thirdly, multiple biological risk factors such as hypertension, diabetes and lipid abnormalities are major predictors of cardiovascular mortality and we have no information on these variables except hypertension results published elsewhere [13]. Fourthly, the study excluded polling stations comprising upper-middle class and upper class housing complexes that were not accessible due to security issues. Similarly, the study excluded homeless persons, such as footpath dwellers, as they were generally excluded from the voter's list. Therefore, the study may not be truly representative of Mumbai or Indian population although more than $80 \%$ of the Indian population lives in social and economic circumstances 
Table 4 Person years, number of deaths, hazard ratios (HRs) and 95\% confidence intervals (Cls) for all-cause, CVD, IHD and stroke mortality in women stratified by educational groups*, Mumbai Cohort Study, Mumbai, Maharashtra, India

\begin{tabular}{|c|c|c|c|c|c|c|}
\hline \multirow[t]{2}{*}{ Women } & \multirow[t]{2}{*}{ Illiterate } & \multirow[t]{2}{*}{ Primary school } & \multicolumn{4}{|c|}{ Middle school and above } \\
\hline & & & Middle school & Secondary school & College & Sub total \\
\hline Person years & 147,971 & 116,063 & 46,739 & 14,145 & 5320 & 66,204 \\
\hline All-deaths (n) & 2417 & 762 & 160 & 54 & 19 & 233 \\
\hline Death rates per $100000^{2}$ & 1444 & 949 & 896 & 981 & 962 & 918 \\
\hline $\begin{array}{l}\mathrm{HR}^{1} \\
95 \% \mathrm{Cl}\end{array}$ & 1.0 & $\begin{array}{c}0.41 \\
(0.38-0.44)\end{array}$ & $\begin{array}{c}0.21 \\
(0.18-0.25)\end{array}$ & $\begin{array}{c}0.24 \\
(0.18-0.31)\end{array}$ & $\begin{array}{c}0.22 \\
(0.14-0.35)\end{array}$ & $\begin{array}{c}0.22 \\
(0.19-0.25)\end{array}$ \\
\hline $\begin{array}{l}\mathrm{HR}^{2} \\
95 \% \mathrm{Cl}\end{array}$ & 1.0 & $\begin{array}{c}0.68 \\
(0.63-0.74)\end{array}$ & $\begin{array}{c}0.61 \\
(0.52-0.72)\end{array}$ & $\begin{array}{c}0.64 \\
(0.49-0.84)\end{array}$ & $\begin{array}{c}0.57 \\
(0.36-0.90)\end{array}$ & $\begin{array}{c}0.61 \\
(0.53-0.71)\end{array}$ \\
\hline $\begin{array}{l}\mathrm{HR}^{3} \\
95 \% \mathrm{Cl}\end{array}$ & 1.0 & $\begin{array}{c}0.72 \\
(0.66-0.79)\end{array}$ & $\begin{array}{c}0.66 \\
(0.56-0.78)\end{array}$ & $\begin{array}{c}0.72 \\
(0.55-0.95)\end{array}$ & $\begin{array}{c}0.66 \\
(0.42-1.04)\end{array}$ & $\begin{array}{c}0.67 \\
(0.58-0.78)\end{array}$ \\
\hline $\begin{array}{l}\mathrm{HR}^{4} \\
95 \% \mathrm{Cl} \\
\end{array}$ & 1.0 & $\begin{array}{c}0.78 \\
(0.71-0.85) \\
\end{array}$ & $\begin{array}{c}0.70 \\
(0.59-0.82) \\
\end{array}$ & $\begin{array}{c}0.77 \\
(0.58-1.02) \\
\end{array}$ & $\begin{array}{c}0.70 \\
(0.44-1.10) \\
\end{array}$ & $\begin{array}{c}0.71 \\
(0.62-0.82) \\
\end{array}$ \\
\hline $\mathrm{CVD}^{5}$ deaths $(\mathrm{n})$ & 721 & 234 & 39 & 24 & 7 & 70 \\
\hline Death rates per $100000^{2}$ & 429 & 301 & 267 & 426 & 317 & 306 \\
\hline $\begin{array}{l}\mathrm{HR}^{1} \\
95 \% \mathrm{Cl}\end{array}$ & 1.0 & $\begin{array}{c}0.41 \\
(0.35-0.47)\end{array}$ & $\begin{array}{c}0.17 \\
(0.12-0.23)\end{array}$ & $\begin{array}{c}0.34 \\
(0.23-0.51)\end{array}$ & $\begin{array}{c}0.26 \\
(0.13-0.56)\end{array}$ & $\begin{array}{c}0.21 \\
(0.16-0.27)\end{array}$ \\
\hline $\begin{array}{l}\mathrm{HR}^{2} \\
95 \% \mathrm{Cl}\end{array}$ & 1.0 & $\begin{array}{c}0.69 \\
(0.60-0.80)\end{array}$ & $\begin{array}{c}0.55 \\
(0.40-0.76)\end{array}$ & $\begin{array}{c}1.04 \\
(0.69-1.57)\end{array}$ & $\begin{array}{c}0.74 \\
(0.35-1.56)\end{array}$ & $\begin{array}{c}0.68 \\
(0.53-0.87)\end{array}$ \\
\hline $\begin{array}{l}\mathrm{HR}^{3} \\
95 \% \mathrm{Cl}\end{array}$ & 1.0 & $\begin{array}{c}0.73 \\
(0.62-0.85)\end{array}$ & $\begin{array}{c}0.59 \\
(0.42-0.82)\end{array}$ & $\begin{array}{c}1.17 \\
(0.77-1.77)\end{array}$ & $\begin{array}{c}0.84 \\
(0.40-1.79)\end{array}$ & $\begin{array}{c}0.73 \\
(0.57-0.95)\end{array}$ \\
\hline $\begin{array}{l}\mathrm{HR}^{4} \\
95 \% \mathrm{Cl}\end{array}$ & 1.0 & $\begin{array}{c}0.75 \\
(0.64-0.88)\end{array}$ & $\begin{array}{c}0.59 \\
(0.42-0.82)\end{array}$ & $\begin{array}{c}1.17 \\
(0.77-1.79)\end{array}$ & $\begin{array}{c}0.79 \\
(0.37-1.69)\end{array}$ & $\begin{array}{c}0.73 \\
(0.56-0.94)\end{array}$ \\
\hline $\mathrm{IHD}^{6}$ deaths $(\mathrm{n})$ & 303 & 106 & 18 & 12 & 3 & 33 \\
\hline Death rates per $100000^{2}$ & 180 & 133 & 131 & 227 & 96 & 142 \\
\hline $\begin{array}{l}\mathrm{HR}^{1} \\
95 \% \mathrm{Cl}\end{array}$ & 1.0 & $\begin{array}{c}0.44 \\
(0.35-0.54)\end{array}$ & $\begin{array}{c}0.18 \\
(0.11-0.29)\end{array}$ & $\begin{array}{c}0.40 \\
(0.23-0.71)\end{array}$ & $\begin{array}{c}0.27 \\
(0.09-0.84)\end{array}$ & $\begin{array}{c}0.24 \\
(0.16-0.34)\end{array}$ \\
\hline $\begin{array}{l}\mathrm{HR}^{2} \\
95 \% \mathrm{Cl}\end{array}$ & 1.0 & $\begin{array}{c}0.73 \\
(0.59-0.92)\end{array}$ & $\begin{array}{c}0.59 \\
(0.37-0.96)\end{array}$ & $\begin{array}{c}1.20 \\
(0.67-2.14)\end{array}$ & $\begin{array}{c}0.74 \\
(0.24-2.31)\end{array}$ & $\begin{array}{c}0.74 \\
(0.52-1.07)\end{array}$ \\
\hline $\begin{array}{l}\mathrm{HR}^{3} \\
95 \% \mathrm{Cl}\end{array}$ & 1.0 & $\begin{array}{c}0.78 \\
(0.62-0.99)\end{array}$ & $\begin{array}{c}0.65 \\
(0.40-1.05)\end{array}$ & $\begin{array}{c}1.39 \\
(0.76-2.53)\end{array}$ & $\begin{array}{c}0.87 \\
(0.28-2.76)\end{array}$ & $\begin{array}{c}0.82 \\
(0.56-1.20)\end{array}$ \\
\hline $\begin{array}{l}\mathrm{HR}^{4} \\
95 \% \mathrm{Cl}\end{array}$ & 1.0 & $\begin{array}{c}0.78 \\
(0.62-0.99)\end{array}$ & $\begin{array}{c}0.61 \\
(0.37-1.00)\end{array}$ & $\begin{array}{c}1.36 \\
(0.74-2.48)\end{array}$ & $\begin{array}{c}0.77 \\
(0.24-2.44)\end{array}$ & $\begin{array}{c}0.78 \\
(0.53-1.14)\end{array}$ \\
\hline Stroke $^{7}$ deaths (n) & 145 & 51 & 9 & 4 & 1 & 14 \\
\hline Death rates per $100000^{2}$ & 87 & 67 & 58 & 47 & 50 & 54 \\
\hline $\begin{array}{l}\mathrm{HR}^{1} \\
95 \% \mathrm{Cl}\end{array}$ & 1.0 & $\begin{array}{c}0.43 \\
(0.32-0.60)\end{array}$ & $\begin{array}{c}0.19 \\
(0.10-0.37)\end{array}$ & $\begin{array}{c}0.28 \\
(0.10-0.75)\end{array}$ & $\begin{array}{c}0.19 \\
(0.03-1.33)\end{array}$ & $\begin{array}{c}0.21 \\
(0.12-0.36)\end{array}$ \\
\hline $\begin{array}{l}\mathrm{HR}^{2} \\
95 \% \mathrm{Cl}\end{array}$ & 1.0 & $\begin{array}{c}0.72 \\
(0.52-1.00)\end{array}$ & $\begin{array}{c}0.60 \\
(0.30-1.19)\end{array}$ & $\begin{array}{c}0.85 \\
(0.31-2.29)\end{array}$ & $\begin{array}{c}0.51 \\
(0.07-3.68)\end{array}$ & $\begin{array}{c}0.65 \\
(0.37-1.13)\end{array}$ \\
\hline $\begin{array}{l}\mathrm{HR}^{3} \\
95 \% \mathrm{Cl}\end{array}$ & 1.0 & $\begin{array}{c}0.76 \\
(0.54-1.06)\end{array}$ & $\begin{array}{c}0.64 \\
(0.32-1.27)\end{array}$ & $\begin{array}{c}0.94 \\
(0.34-2.59)\end{array}$ & $\begin{array}{c}0.58 \\
(0.08-4.17)\end{array}$ & $\begin{array}{c}0.69 \\
(0.39-1.24)\end{array}$ \\
\hline $\begin{array}{l}\mathrm{HR}^{4} \\
95 \% \mathrm{Cl}\end{array}$ & 1.0 & $\begin{array}{c}0.78 \\
(0.55-1.10)\end{array}$ & $\begin{array}{c}0.64 \\
(0.32-1.29)\end{array}$ & $\begin{array}{c}0.95 \\
(0.34-2.63)\end{array}$ & $\begin{array}{c}0.57 \\
(0.08-4.17)\end{array}$ & $\begin{array}{c}0.70 \\
(0.39-1.25)\end{array}$ \\
\hline
\end{tabular}

*Illiterate, Primary school ( $\leq 5$ years of formal education), Middle school (6-8 years), Secondary school (9-10 years) and College ( $>10$ years)

${ }^{1}$ crude hazard ratios (HRs), ${ }^{2}$ adjusted for age, ${ }^{3}$ adjusted for age and tobacco use, ${ }^{4}$ adjusted for age, tobacco use, BMl, religion and mother tongue, ${ }^{5}$ all circulatory system related deaths (ICD-10 codes 100-99), ${ }^{6}$ Ischemic Heart Disease deaths (I20-25), ${ }^{7}$ cerebrovascular deaths (I60-69)

as observed in the present study [31]. And finally, there are multiple measures of socioeconomic status including area-based measures, housing type, occupation, ownership, income, and others, apart from educational status. We used educational status as it has been shown to be the most robust and are the most widely used estimate [16]. Moreover, educational status is acquired in early childhood and does not change with evolving social phenotype [32] and studies in India and other low income countries have shown good correlation with multiple markers of socioeconomic status $[7,27]$. This is study strength. Other strengths mainly includes a population based nature of the cohort, very large sample size that is much more than many of the earlier studies, and first time use of hand-help computers (electronic diaries) for house to house data collection using face-to- 
face interviewers in the second most populous country in the world.

The Whitehall study reported the lowest mortality in the most educated professional and executive class and the greatest in menial workers [32-34], which was similar to what we observed for all-causes mortality in this study (Table 3,4 ). This has been attributed to multiple sociological and biological determinants of health. Less literate and poor people led to unhealthy lifestyles in terms of smoking, diet and physical activity [35]. However, adjustments for several known CVD risk factors (smoking, lipids, blood pressure and diabetes) did not completely attenuate the trends and Marmot believes that the social (educational) differences in mortality could be due to factors leading to social stress such as inequality, lack of autonomy, selfesteem and social participation [36] Other social determinants of CVD health include stress, early life events, social exclusion, improper working conditions, lack of social support, addictions including tobacco and alcohol, food scarcity or excess and uneven distribution and lack of proper transport [37]. The information was not available for most of these risk factors in our study but another study from rural India reported that subjects with low educational status have inferior housing, inferior job status, improper working conditions, crowded housing and greater tobacco and alcohol use [7]. On the other hand many US studies have used educational status as a marker of socioeconomic status and reported that low educational status is an important determinant of CVD incidence and mortality. It has also been shown that those with low educational status have a lifetime risk of suffering from diseasesinfections and nutrition related diseases in childhood and chronic diseases including CVD in adulthood. ${ }^{16}$ Multiple socio-biological pathways have been implicated [35,38]. This is similar to the present study where both all-cause and CVD mortality was greater among the illiterate and those with low educational status. These findings are further strengthened by observation of the survival curves (Figure 2). An important observation in the present study was a clear association of illiteracy and low educational status with increased CVD mortality in men (Table 3) while the situation was not clear in women (Table 4). This could possibly be due to the fact that only a few women had education above secondary level $(\sim 6 \%)$ and the numbers of deaths observed in these groups were small. Indeed, if the data for women in more literate Groups (middle school, secondary and college) were combined in a single group the trend appears similar to those in men (Table 3, 4). Similarly, no clear associations for mortality due to IHD and stroke could also be due to lower absolute numbers. In women, the prevalence of illiteracy is high and it is known that in such circumstances, the association of literacy and chronic diseases deaths are often unclear. Previous studies in high income countries have reported that illiterate and low educational status women and men are equally at greater risk of cardiovascular deaths $[39,40]$.

Illiteracy and low-literacy status is rampant in lowincome countries [1]. Macro level evidence from high income countries suggest that improvement in literacy status, which is outside the purview of traditional public health approaches to disease prevention and management, decreases chronic diseases risk factors [41]. Greater literacy status leads to increased awareness of health risk factors at population as well as individual level. It is also associated with greater use of strategies to decrease risk factors and adherence to health promoting behaviours and therapies. This leads to decline in the three primordial as well as proximate chronic disease risk factors. Use of appropriate healthcare system and evidence based therapies for CVD treatment and control is also greater among the more literate subjects. In India and other low income countries social and biological pathways of increased CVD risk among the low educational status subjects have not been well studied and more prospective studies are needed to identify pathways to lowered risk. Over $80 \%$ of world's deaths from CVDs occur in low-and middle-income countries, such as India; where people are more exposed to risk factors leading to diseases and have less access to health care services and prevention efforts than people in highincome countries. As a result, many people die younger, often in their most productive years. In 2005, of the total projected deaths $(10,362,000)$ in India around $28 \%$ were from CVDs. At household level, sufficient evidence is emerging to prove that CVDs and other NCDs contribute to poverty. For example, catastrophic health care expenditures for household with a family member with CVD can be $30 \%$ or more of annual household spending. Also in 2005 alone, it was estimated that India will lose $\$ 9$ billion and will further continue to lose \$ 237 billion in next 10 years in National Income from premature deaths due to heart disease, stroke and diabetes [42].

\section{Conclusions}

Cost-effective interventions exist, and have worked in many countries: the most successful strategies have employed a range of population-wide approaches combined with interventions for individuals. Therefore, current study not only help identifying high risk group (i.e. individuals with low education) for CVDs but underscores the urgent need to direct our efforts to under privilege, which is the largest section of most developing countries like India. Additionally the study 
demonstrated that improving educational status may result in preventing $\sim 9 \%$ premature male and female deaths. Amartya Sen [43], the noted economist, opines that even when an economy is poor, major health improvements can be achieved through using the available resources in socially productive way such as improving population education. Clearly improving educational status should be high priority for achieving good cardiovascular health.

\section{Additional material}

Additional file 1: Demographic details of the study subjects and comparison of subjects who were available for follow-up and those lost to follow-up

\section{Acknowledgements and Funding}

This work was supported by the International Agency for Research on Cancer, Lyon, France (Collaborative Research Agreement DEP/89/12), the Clinical Trial Service Unit of the University of Oxford, Oxford, United Kingdom, and the World Health Organization Geneva, Switzerland. All of these entities provided funding for the study. The authors wish to acknowledge the cooperation of the Municipal Corporation of Greater Mumbai (BMC) for providing access to the cause-of-death information. The authors thank entire field and study staff for their valuable contribution to the study.

\section{Author details}

${ }^{1}$ Healis Sekhsaria Institute for Public Health, CBD Belapur, Navi Mumbai, Maharashtra-400614, India. '2Department of Medicine, Fortis Escorts Hospital, Malviya Nagar, Jaipur-302017, India.

\section{Authors' contributions}

MSP and RG developed the concept for this paper. MSP directed the field work, was responsible for the data management, data analyses and the statistical procedures and tests, interpreted the results, conducted the literature search, and interacted with co-authors in subsequent drafts of the paper. RG was also responsible for assisting with data analysis, interpretation of results, and writing of the paper at all stages. PCG conceptualized the Mumbai cohort study, evolved field instruments and procedures, directed the field work, data management and data analyses, interpreted the results and contributed towards writing of the paper at all stages. All authors read and approved the final manuscript.

\section{Competing interests}

The authors declare that they have no competing interests.

Received: 18 November 2010 Accepted: 15 July 2011

Published: 15 July 2011

\section{References}

1. Leon DA, Walt G: Poverty inequality and health: an international perspective Oxford. Oxford University Press; 2001.

2. Marmot M, Wilkinson RG: Social determinants of health Oxford Oxford University Press; 1999.

3. Berkman LF, Kawachi I: Social Epidemiology New York Oxford University Press; 2000.

4. Marmot M: Harveian oration: Health in an unequal world. Lancet 2006, 368:2081-2094.

5. Gupta R, Gupta KD: Coronary heart disease in low socioeconomic subjects in India: an emerging epidemic. Indian Heart J 2009, 61:358-367.

6. Sapru RP: An overview of cardiovascular diseases in India. In Preventive cardiology: an introduction. Edited by: Wasir HS. New Delhi Vikas Publishing House; 1991:69-86.
7. Gupta R, Gupta VP, Ahluwalia NS: Educational status, coronary heart disease and coronary risk factor prevalence in a rural population of India. BMJ 1994, 309:1332-1336.

8. Pais P, Pogue J, Gerstein H, Zachariah E, Savitha D, Jayaprakash S, Yusuf S: Risk factors for acute myocardial infarction in Indians: a case-control study. Lancet 1996, 348:358-363.

9. Rosengren A, Subramanian SV, Islam S, Chow CK, Avezum A, Kazmi K, Sliwa K, Zubaid M, Rangarajan S, Yusuf S, for the INTERHEART investigators: Education and risk for myocardial infarction in 52 high, middle and low income countries: INTERHEART case control study. Heart 2009, 95:2014-2022.

10. Xavier D, Pais P, Devereaux PJ, Xie C, Prabhakaran D, Reddy KS, Gupta R, Joshi P, Kerkar P, Thanickachalam S, Haridas KK, Jaison TM, Naik S, Maity AK, Yusuf S, on behalf of the CREATE Registry Investigators: Treatment and outcomes of acute coronary syndromes in India (CREATE): a prospective analysis of registry data. Lancet 2008, 371:1435-1442.

11. Pednekar MS: The impact of Tobacco Use and/or Body Composition on Adult Mortality in Urban Developing Country Population. Acta Universitatis Tamperensis 1340, Tampere University Press, Tampere; 2008 [http://acta.uta.fi/pdf/978-951-44-7431-6.pdf].

12. Gupta PC, Pednekar MS, Parkin DM, Sankarnarayanan R: Tobacco associated mortality in Mumbai (Bombay) India. Results from the Bombay Cohort Study. Int J Epidemiol 2005, 34:1395-1402.

13. Pednekar MS, Gupta R, Gupta PC: Association of blood pressure and cardiovascular mortality in India: Mumbai Cohort Study. Am J Hypertens 2009, 22:1076-1084.

14. Pednekar MS, Hakama M, Hebert JR, Gupta PC: Association of body mass index with all-cause and cause-specific mortality: findings from a prospective cohort study in Mumbai, India. Int J Epidemiol 2008, 37:524-535.

15. Russel B: Education and social order (1932). New York Routeledge Classics; 2009.

16. Kaplan GA, Keil JE: Socioeconomic factors and cardiovascular disease: a review of the literature. Circulation 1993, 88:1973-1998.

17. Kelly MJ, Weitzen S: The association of lifetime education with the prevalence of myocardial infarction: an analysis of the 2006 Behavioral Risk Factor Surveillance System. J Comm Health 2010, 35:76-80.

18. Bucher HC, Ragland DR: Socioeconomic indicators and mortality from coronary heart disease and cancer: a 22 year follow-up of middle aged men. Am J Public Health 1995, 85:1231-6.

19. Steenland K, Henley M, Thun M: All-cause and cause specific death rates by educational status for two million people in two American Cancer Society cohorts: 1959-1996. Am J Epidemiol 2002, 156:11-21.

20. Avendano A, Kunst AE, Huisman M, Lenthe FV, Bopp M, Regidor $E_{\text {, }}$ Glickman M, Costa G, Spadea T, Deboosere P, Borrell C, Valkonen T, Gisser R, Borgan JK, Gadeyne S, Mackenbach JP: Socioeconomic status and ischemic heart disease mortality in 10 western European populations during the 1990s. Heart 2006, 92:461-467.

21. Lawlor DA, Ebrahim S, Davey Smith G: Adverse socioeconomic position across the lifecourse increases coronary heart disease risk cumulatively, findings from the British women's heart and health study. J Epidemiol Comm Health 2005, 59:785-793.

22. Laaksonen M, Talala K, Martelin T, Rahkonen O, Roos E, Helakorpi S, Laatikainen T, Prättälä R: Health behaviours as explanations for educational level differences in cardiovascular and all-cause mortality: a follow-up of 60,000 men and women over 23 years. Eur J Public Health 2008, 18:38-43

23. McWilliams JM, Meara E, Zaslavsky AM, Ayanian JZ: Differences in control of cardiovascular disease and diabetes by race, ethnicity, and education: US trends from 1999 to 2006 and effects of mediocre coverage. Ann Intern Med 2009, 150:505-515.

24. Teo KK, Chow CK, Vaz M, Rangarajan S, Yusuf S: The Prospective Urban Rural Epidemiology (PURE) study: Examining the impact of societal influences on chronic non-communicable diseases in low, middle and high-income countries. Am Heart J 2009, 158:1-7.

25. Schooling CM, Jiang CQ, Lam TH, Zhang WS, Cheng WS, Cheng KK, Leung JM: Life-course origins of social inequalities in metabolic risk in the population of a developing country. Am J Epidemio/ 2008, 167:419-428.

26. Gupta R, Gupta VP, Sarna M, Prakash H, Rastogi S, Gupta KD: Serial epidemiological surveys in an urban Indian population demonstrate 
increasing coronary risk factor among the lower socioeconomic strata. J Assoc Physicians Ind 2003, 55:470-477.

27. Reddy KS, Prabhakaran D, Jeemon P, Thankappan KM, Joshi PP, Chaturvedi V, Ramakrishnan L, Ahmed F: Educational status and cardiovascular risk profile in Indians. Proc Natl Acad Sciences 2007, 104:16263-68

28. Gupta R, Agrawal A, Sarna M, Kaul V, Gupta VP: High cardiovascular disease risk in low socioeconomic groups in India. CVD Prev Control 2009, 4(Suppl 1):S118-119.

29. Gupta PC, Gupta R, Pendnekar M: Hypertension prevalence and blood pressure trends in 88,653 subjects in Mumbai, India. J Hum Hypertens 2004, 18:907-910.

30. Prospective Studies Collaboration, Whitlock G, Lewington S, Sherlikar $P$, Clarke R, Emberson J, Halsey J, Qizilbash N, Collins R, Peto R: Body mass index and cause specific mortality in 900,000 adults: collaborative analyses of 57 prospective studies. Lancet 2009, 373:1083-1096.

31. Panagariya A: India: the emerging giant New York. Oxford University Press; 2009

32. Marmot MG, Adelstein AM, Robinson N, Rose GA: Changing social class distribution of heart disease. BMJ 1978, ii:1109-1112

33. Rose GA, Marmot MG: Social class and coronary heart disease. Br Heart $J$ 1981, 45:13-19.

34. Hemingway H, Shipley M, Macfarlane P, Marmot M: Impact of socioeconomic status on coronary mortality in people with symptoms, electrocardiographic abnormalities, both or neither: the original Whitehall study 25 year follow up. J Epidemiol Comm Health 2000, 54:510-516.

35. Wamala SP, Mittleman MA, Schenck-Gustafsson K, Orth-Gomér K: Potential explanations for the educational gradient in coronary heart disease: a population based case-control study of Swedish women. Am J Public Health 1999, 89:315-321.

36. Marmot M: Status Syndrome: How social standing affects our health and longevity New York Holt Paperbacks; 2004

37. Marmot M: Social determinants of health inequities. Lancet 2005, 365:1099-1104.

38. Stansfeld SA, Marmot M: Stress and the heart: psychosocial pathways to coronary heart disease. London BMJ Books 2002.

39. Thurston RC, Kubzansky LD, Kawachi I, Berkman LF: Is the association between socioeconomic position and coronary heart disease stronger in women than in men? Am J Epidemiol 2005, 162:57-65.

40. Strand BH, Tverdal A: Can cardiovascular risk factors and lifestyle explain the educational inequalities in mortality from ischemic heart disease and from other heart diseases? 26 year follow up of 50,000 Norwegain men and women. J Epidemiol Comm Health 2004, 58:705-709.

41. Kamerow D: Today's doctors dilemma: the secret to a longer life is nothing we can do anything about in health care. BMJ 2007, 334:126.

42. WHO: Preventing chronic diseases: a vital investment: WHO global report. WHO Geneva; 2005

43. Sen A: Health achievement and equity: external and internal perspectives. In Public health, ethics and equity. Edited by: Anand S, Peter F, Sen A. Oxford. Oxford University Press; 2004:263-268.

\section{Pre-publication history}

The pre-publication history for this paper can be accessed here: http://www.biomedcentral.com/1471-2458/11/567/prepub

\section{Submit your next manuscript to BioMed Central and take full advantage of:}

- Convenient online submission

- Thorough peer review

- No space constraints or color figure charges

- Immediate publication on acceptance

- Inclusion in PubMed, CAS, Scopus and Google Scholar

- Research which is freely available for redistribution

Submit your manuscript at www.biomedcentral.com/submit
Ciomed Central 